日植病報 XXIV, (2) : 104 108（1959）

\title{
微生物に対する放射線の影響（第3 報）
}

\author{
稲胡麻葉枯病菌分生胞子発芽に及ぼす紫外線の影響（その 1 )* \\ 正子 朔**
}

Hajime Masago : Studies on the effects of radiation on microorganisms. (3) Influence of ultraviolet light on conidial germination of Cochliobolus miyabeanus (Part 1).

\section{1. 緒言}

紫外線照射による殺菌および做生物の生長抑制に就 いては往来多くの報告があり，著者も 1,2 検討を加 えてきたが1)，更に稻淜麻葉枯病菌分生胞子の発芽と 紫外線量との関係を追求した。㽞来照射実験には人工 太陽灯が用いられていたが，近年殺菌ランプとして低 圧水銀灯が市販されるよ5になつたのでそれらの殺菌 エネルギーを定量的に比較して殺菌効果を榆討するこ とは, 紫外線の殺菌機構解明にも重要なことである。 一般に, 糸状菌の発育は細菌に比べて緩慢であるから, 生理作用に及ぼす紫外線の影響を調べるには湖麻葉枯 病菌は好適な材料である。かつ同菌の分生胞子は隔膜 をもつているが，これによつて隔てられた細胞間の関 係の追求 ${ }^{2}$ は単に殺菌現象の追求のみならず, 胞子の 発芽生理とい5点からも興味ある問題である。以下 2 , 3 得られた結果を緾めて報告する。

\section{2. 実 験 結 果}

A. 人エ太陽灯と殺菌灯の殺菌力比較 供試した 人工太陽灯は高圧水銀灯で点灯淔後に殺菌線測定用の 螢光板に緑色螢光を与えるが，この螢光は寸時にして 消滅してしま5。供試菌は子め麦芽煎汁寒天斜面に 20 日間培養したもので, 人工太陽灯, 殺菌灯何れの場合 にも線源から $15 \mathrm{~cm}$ のところに供試菌の分生胞子懸 㽚液を置いて照射した後直ちに $28^{\circ} \mathrm{C} て ゙$ 発芽試験を行 つた結果は第 1 表の如くである。

これにより明らかなように，人工太陽灯の発芽抑制 乃至殺菌力は殺菌灯のそれに比べて乿かに及ばない。 これは恐らく含まれている水銀スペクトルの相違に基 ずくものであろ5。

* 京都大学農学部植物病理学研究室業績, 第 115 号 ** 京都大学農学部植物病理学研究室

\section{B. 胞子の乾湿環境条件の 相連が紫外線感受性} に及ぼす影響 通常固体培地上に生成された菌類胞子 は大体乾燥状態にあるものと見做されている。したが つてそれをそのままスライドグラス上に散布して紫 外線を照射した場合と, 分生胞子を蒸留水に䀣濁して スライドグラス上に点滴後紫外線を照射した場合との 胞子の感受性を比較した。第 2 表は稲乩麻葉枯病菌第 13 号菌を麦芽寒天培地上に $28^{\circ} \mathrm{C}$ で 15 日間培養した 後, $1,020 \mu \mathrm{w} / \mathrm{cm}^{2}$ の紫外線照射を行つたものの発芽: 状況 (10時間後) である (第 1 図参照)。

上表の結果から分生胞子を水に浸すと紫外線に対す る感受性が高まることが明らかとなつたが，これは発 芽作用に関与する細胞の活性度が向上したために起つ たものであるう。

C. 紫外線による発芽抑制 紫外線照射を行 万場合 照射された菌の生死鑑別は通常発芽の有無によつて行 つている。しかし照射後の時間経過によつて発芽 率に可成りの変化が見られるのでこれを確めるた めに次の実験を行つた。麦芽寒天培地 $(\mathrm{pH} \mathrm{5.8)} \mathrm{上}$ に稲乩麻葉枯病菌第 58 および第 13 号菌を 5 日間 $28^{\circ} \mathrm{C}$ で培養し，生じた分生胞子を Czapek 液で洗い落し た。その使濁液を直ちに 2,000 r. p. m., 5 分間の 遠心分離によつて胞子を沈澱せしめ，との上澄みを 捨ててこの操作を 3 回反復し, Czapek 液でよく胞子 を洗涤した。洗涤後, この分生胞子を再び Czapek 液中に懸濁して, その液をスライド上に点滴して, 紫 外線射照を行つた。この場合の照射エネルギーは975 $\mu \mathrm{w} / \mathrm{cm}^{2}$ であつた。

照射処理後はスライドグラスを肉池でつくつた湿室 に入れ, $28^{\circ} \mathrm{C}$ の恒温器内に所定時間保つた。各時間 における供試両系菌の発芽状況は第 3 表, 第 4 表の通 りで，何れも 3 回実験の総合結果である（第 2 図, 第 3 図参照)。

紫外線に対する感受性の大小を調べるには照射後あ 
第 1 表 稲乩麻葉枯病菌第 13 号菌の分生胞子発芽におよほす

人工太陽灯あるいは殺菌灯からの紫外線の影響

Table 1. Influence of ultraviolet light (sun lamp and germicidal lamp) upon condial germination of Cochliobolus miyabeanus, isolate No. 13.

\begin{tabular}{|c|c|c|c|c|c|c|}
\hline \multirow{2}{*}{$\begin{array}{l}\text { 照 射 時 間 } \\
\text { Irradiation } \\
\text { time } \\
\text { min. }\end{array}$} & \multicolumn{3}{|c|}{ 工 ${ }_{\text {Sun lamp }}^{\text {太陽 }}$} & \multicolumn{3}{|c|}{ Germicidal lamp 菌 } \\
\hline & $\begin{array}{l}\text { 供試胞子数 } \\
\text { Spores } \\
\text { examined }\end{array}$ & $\begin{array}{l}\text { 発䓔胞子数 } \\
\text { Spores } \\
\text { germinated }\end{array}$ & $\begin{array}{l}\text { 発 芽 率* } \\
\text { Percentage } \\
\text { of } \\
\text { germination } \%\end{array}$ & $\begin{array}{c}\text { 供試胞子数 } \\
\text { Spores } \\
\text { examined }\end{array}$ & $\begin{array}{l}\text { 発芽胞子数 } \\
\text { Spores } \\
\text { germinated }\end{array}$ & $\begin{array}{c}\text { 発 茅 率* } \\
\text { Percentage } \\
\text { of } \\
\text { germination } \%\end{array}$ \\
\hline 0 & 1,020 & 1,020 & 100 & 1,024 & 1,024 & 100 \\
\hline 2.5 & 936 & 936 & 100 & 1,088 & 608 & 56 \\
\hline 5.0 & 960 & 960 & 100 & 876 & 156 & 18 \\
\hline 7.5 & 972 & 972 & 100 & 848 & 32 & 4 \\
\hline 10.0 & 828 & 816 & 98 & 1,008 & 36 & 3.5 \\
\hline 12.5 & 816 & 720 & 88 & 1,056 & 16 & 1.5 \\
\hline 15.0 & 1,032 & 912 & 88 & 1,080 & 0 & 0 \\
\hline
\end{tabular}

* Percentage of germination after $10 \mathrm{hrs}$.' incubation under $28^{\circ} \mathrm{C}$.

第 2 表 稻湖麻葉枯病菌第 13 号菌の分生胞子発芽に拈よぼす

紫外線の影響(照射時に扣ける分生胞子の状態と発芽の比較)

Table 2. Influence of ultraviolet light upon the conidial germination of C. miyabeanus, isolate No. 13 (Comparison of moisture condition under which conidia were irradiated.).

\begin{tabular}{|c|c|c|c|c|c|c|c|}
\hline \multirow{2}{*}{ 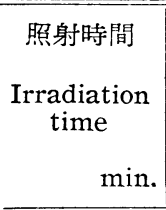 } & \multirow{2}{*}{$\begin{array}{c}\text { 照射量 } \\
\text { Dose } \\
\mu \mathrm{w}-\mathrm{min} / \mathrm{cm}^{2}\end{array}$} & \multicolumn{3}{|c|}{ 乾 Dry condition 燥 } & \multicolumn{3}{|c|}{ Wet condition } \\
\hline & & $\begin{array}{c}\text { 供試胞子数 } \\
\text { Spores } \\
\text { examined }\end{array}$ & $\begin{array}{c}\text { 発芽胞子数 } \\
\text { Spores } \\
\text { germinated }\end{array}$ & $\begin{array}{l}\text { 発 茅 率* } \\
\text { Percentage } \\
\text { of } \\
\text { germination } \\
\%\end{array}$ & $\begin{array}{c}\text { 供試胞子数 } \\
\text { Spores } \\
\text { examined }\end{array}$ & $\begin{array}{c}\text { 発芽胞子数 } \\
\text { Spores } \\
\text { germinated }\end{array}$ & $\begin{array}{c}\text { 発 芽 率* } \\
\text { Percentage } \\
\text { of } \\
\text { germination \% }\end{array}$ \\
\hline 0 & 0 & 823 & 806 & 98 & 794 & 765 & 96 \\
\hline 2.5 & 2,550 & 878 & 773 & 88 & 732 & 677 & 92 \\
\hline 5.0 & 5,000 & 734 & 606 & 82 & 848 & 326 & 39 \\
\hline 7.5 & 7,650 & 666 & 363 & 54 & 940 & 130 & 14 \\
\hline 10.0 & 10,200 & 1,056 & 91 & 28 & 1,172 & 56 & 5 \\
\hline 12.5 & 12,750 & 1,284 & 84 & 6.6 & 1,172 & 26 & 2.3 \\
\hline
\end{tabular}

* Percentage of germination after $10 \mathrm{hrs}$.' incubation under $28^{\circ} \mathrm{C}$.

る程度以上の時間の経過を必要とする。すなわち照射 は発芽遅滞を起すが，死に至らしめない場合が多いか らである。第 13 号菌と第 58 号菌とを比較した場合 に，前者が紫外線に強いようである。

\section{4. 論議}

著者は殺菌線照度計を自作して照射エネルギーを 湘定したが，人工太陽灯は点灯直後に $2537 \AA$ の紫 外線によつて励起された螢光を発するのみで, 瞬時に
消滅してしま5。これは沶とらく多量に存在する水銀 原子のため，殺菌に有効な $2537 \AA$ 線が吸収されて しまう結果であろうと考えられる。一方低圧水銀灯は 強い緑色螢光を持続的に発している。徉つてある時間 内に打倊殺菌エネルギーは前者において後者より もはるかに少ない䇺である。一定時間の照射では第 1 表のよ うに, 人工太陽灯は殆んど効果を表わさないが 低圧水銀灯は眀らかな発芽抑制効果を示している。こ のことは，照度計の示度によつても明らかなように， 


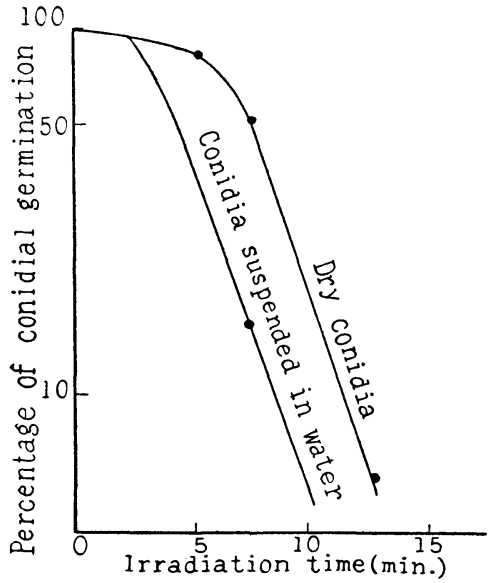

第 1 図 紫外線照射を受けた分生胞子の発芽 に対する水分条件の影響

Fig. 1. Influence of moisture condition upon the germination of conidia irradiated with ultraviolet light.
殺菌に有効なスペクトル域の欠除ということに原因す る。一般に分生胞子の発芽は胞子が水あるいは培養液 中に入れられてから開始するものと考えられるが，分 生胞子を水に浸けた場合と乾燥のままとでは，前者の 方が紫外線に感じ易かつた。このことは著者の興味を 著しく若いたが，水は紫外線を吸収するのでその中に 䯚濁された微生物は紫外線を直接に受ける場合よりも 保護されている筈である。しかし結果は全く反対であ つた。このことは，分生胞子を水浸することによつて 胞子が紫外線に弱い状態に変つたものとしか考えられ ない。すなわち発芽現象が始まると休眠状態の胞子よ りも紫外線に弱くなるということである。しかし，胞 子の発芽が進んで菌糸になると分生胞子よりもかえつ て紫外線に対して強くなるから胞子発芽の過程のどの 段階かに紫外線に極めて鋭敏な時期があるものと考え られる。もつとも X線のような電離放射線照射の場合 には，媒体である水が電離を起してその結果生ずる Free Radical が間接的に働いてその代謝を阻害する

第 3 表 稲胡麻葉枯病菌第 58 号菌の分生胞子発芽に拉よほす紫外線の影響

Table 3. Influence of ultraviolet light upon the conidial germination of

C. miyabeanus, isolate No. 58 .

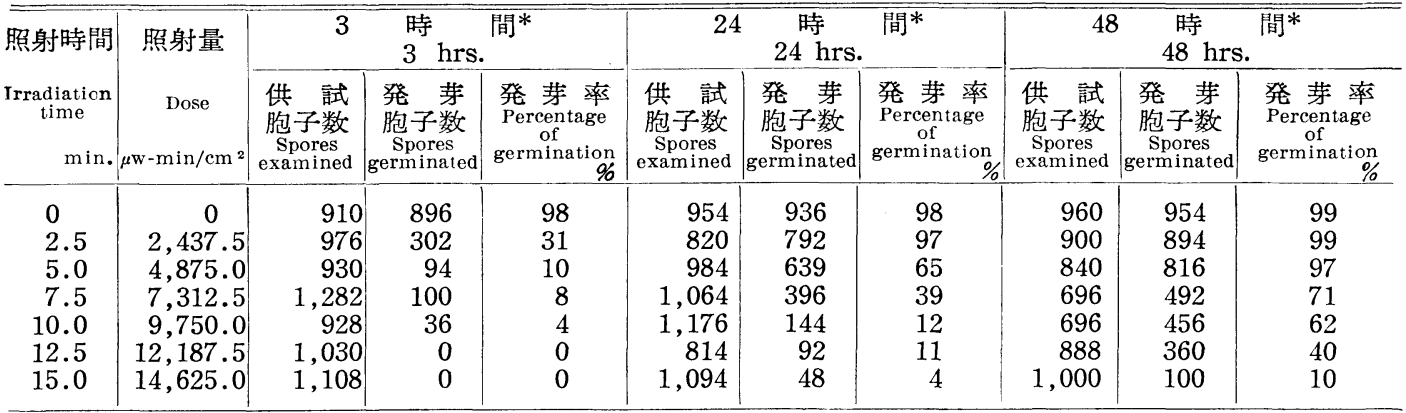

* Time passed after irradiation.

第 4 表 稲乩麻葉枯病菌第 13 号菌の分生胞子発芽に括よぼす紫外線の影響

Table 4. Influence of ultraviolet light upon the conidial germination of C. miyabeanus, isolate No. 13.

\begin{tabular}{|c|c|c|c|c|c|c|c|}
\hline & & 3 & 3 hrs. & 間* & 24 & $\begin{array}{c}\text { 時 } \\
24 \mathrm{hrs} \text {. }\end{array}$ & 間* \\
\hline $\begin{array}{c}\text { Irradiation } \\
\text { time } \\
\text { min. }\end{array}$ & $\begin{array}{c}\text { Dose } \\
\mu \mathrm{w}-\mathrm{min} / \mathrm{cm}^{2}\end{array}$ & $\begin{array}{c}\text { 供試胞子数 } \\
\text { Spores } \\
\text { examined }\end{array}$ & $\begin{array}{c}\text { 発芽胞子数 } \\
\text { Spores } \\
\text { germinated }\end{array}$ & $\begin{array}{c}\text { 発 芽率 } \\
\text { Percentage } \\
\text { of } \\
\text { germination } \\
\%\end{array}$ & $\begin{array}{c}\text { 供試胞子数 } \\
\text { Spores } \\
\text { examined }\end{array}$ & $\begin{array}{c}\text { 発芽胞子数 } \\
\text { Spores } \\
\text { germinated }\end{array}$ & $\begin{array}{c}\text { 発莪率 } \\
\text { Percentage } \\
\text { of } \\
\text { germination } \\
\%\end{array}$ \\
\hline $\begin{array}{r}0 \\
2.5 \\
5.0 \\
7.5 \\
10.0 \\
12.5 \\
15.0\end{array}$ & $\begin{array}{r}0 \\
2,437.5 \\
4,875.0 \\
7,312.5 \\
9,750.0 \\
12,187.5 \\
14,625.0\end{array}$ & $\begin{array}{l}1,179 \\
1,158 \\
1,176 \\
1,052 \\
1,000 \\
1,024 \\
1,152\end{array}$ & $\begin{array}{r}1,062 \\
68 \\
26 \\
6 \\
0 \\
0 \\
0\end{array}$ & $\begin{array}{l}90 \\
6 \\
2 \\
0.6 \\
0 \\
0 \\
0\end{array}$ & $\begin{array}{l}1,150 \\
1,455 \\
1,275 \\
1,104 \\
1,040 \\
1,216 \\
1,392\end{array}$ & $\begin{array}{r}1,130 \\
1,400 \\
1,090 \\
756 \\
596 \\
560 \\
432\end{array}$ & $\begin{array}{l}98 \\
96 \\
85 \\
68 \\
57 \\
34 \\
31\end{array}$ \\
\hline
\end{tabular}

* Time passed after irradiation. 


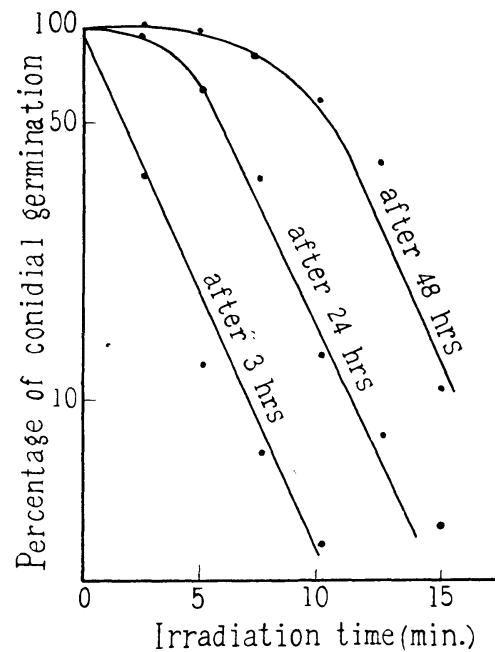

第 2 図稲胡麻葉枯病菌第 58 号菌の紫外線 による発芽阻害の時間的恢復

Fig. 2. Influence of time elapsed after irradiation upon recovery from ultraviolet injury of C. miyabeanus, isolate No. 58 .

ことが知られている。 しかし紫外線の場合にこれを そのまま適用することはできない。しかして紫外線の この殺菌作用は明暸なものではなく，むしろ菌の発育 を抑制する作用と考える方が妥当のよ5である。すな わち第 3 表および第 4 表に見られる如く，紫外線量の 少ない時の分生胞子発芽は若干の遅滞を見つつも殆ん ぞ正常に近い值にまで回復している。従つて観察時間 が短かいときには，発芽漣滞を起している菌と完全に 死滅した菌との間の区別が困難であつてすべてを“死” と算定する誤りを侵し勝ちである。この場合 10,000 $\mu \mathrm{w}-\mathrm{min} / \mathrm{cm}^{2}$ 位の照射量では発芽遅滞の占める割合が 多く, $15,000 \mu \mathrm{w}-\mathrm{min} / \mathrm{cm}^{2}$ 以上では殺されるものの 割合が著しく增加してくる。

供試菌の系統による紫外線感受性の相違は可成り判 然とあらわれるよ5で第 13 号菌は第 58 号菌よりも紫 外線に強いが，この原因は未だ不眀である。

\section{5. 摘 要}

人工太陽灯の殺菌効果は殺菌灯に滛かに及ばない。

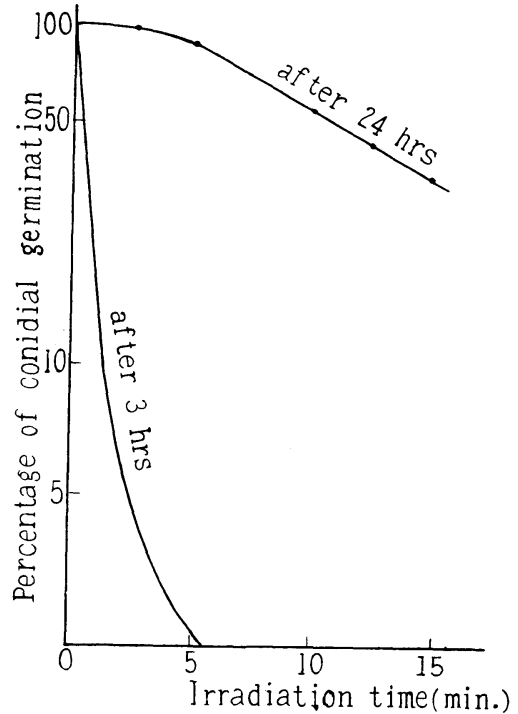

第 3 図稲测麻葉枯病菌第 13 号菌の紫外線 による発来阻害の時間的恢復

Fig. 3. Influence of time elapsed after irradiation upon recovery from ultraviolet injury of C. miyabeanus, isolate No. 13.

これは殺菌に有効な $2537 \AA$ 線が殆んど含まれていな いことによるのである。分生胞子は水浸によつて急激 に紫外線に鋭敏になるがその原因は未だ不明である。 しかして紫外線による殺菌効果の有無を分生胞子の発 芽によつて検定する場合には，発芽の荤滞があるので 少なくとも 24 時間以上経過後発芽率の検定を行わな いと䛊りが多い。稲胡麻葉枯病菌の菌系間には紫外線 に対する感受性の異るものがあり，第 58 号菌は第 13 号菌よりも鋭敏なようである。

本実験実施に当つて御懇篤なる御指導を賜わり，か つ論文の御校閲を賜わつた恩師赤井重恭教授に深甚な る謝意を表します。(1959年 4 月13日受理)

\section{引用 文 献}

1) 正子 朔 (1959), 日植病報, 24 (2):97 103.

2）八木広男，平田幸治（1957）, 日植病報，22：4

3) Whitcher, S. L., et al. (1953), Nucleonics, $11(8): 30$.

\section{Summary}

In the present paper, the writer reported the result of investigations on the influence of light upon the conidial germination of Cochliobolus miyabeanus.

The lethal effect of a sun lamp was far inferior to that of a germicidal lamp, because the 
former scarcely includes the effective wave length for sterilization, $2537 \AA$.

A sudden increase of the sensitivity of conidia to ultraviolet light was observed, when the conidia were suspended in water. The reason is not yet clear.

In the present experiment, the writer estimated the germicidal effect of ultraviolet light by determining the percentage of conidial germination. In view of occurrence of delayed germination, the germination percentage was determined at least 24 hours after the irradiation.

Difference in the sensitivity of conidia to ultraviolet light was found among the isolates of $C$. miyabeanus, the isolate No. 58 being more sensitive than the isolate No. 13.

(Laboratory of Plant Pathology, College of Agriculture, Kyoto University, Kyoto)

\section{文献 紹 介}

\section{キュウリモザイクウイルスの純化と抗血清の作製}

Tomlison, J. A., R. J Shepherd, and J.C. Walker : Purification, properties, and serology of cucumber mosaic virus. Phytopath., 49 ( 5 ): 293 299. (1955).

今迄にも $\mathrm{CMV}$ の純化や形態，抗血清等に関する 研究は行われているが，その方法はまだ確立されて いない。著者等は CMV に罹病したタバコを用い， ブタノール (8.5\%) と低速遠沈(5000 r.p.m., 10 min.) による夾雑物の除去，及び酿酸添加（pH 5.0）と超 遠心分離によるウイルスの沈搌とを組合せて純化に 成功し，径 $40 \mathrm{~m} \mu$ の球状粒子を観察した。汁液の 酸化防止には thioglycollic acid を加兄た。抗血清 は $\mathrm{CMV}$ 罹病タバコ汁を部分的に純化し，それを鬼 に 4〜5 日間隔で 6 回注射して得られた。力価は 1 ：1024であるが健全タバコ汁とも弱い反応を示し た。その他接種葉（タバコ）のウイルス増殖曲線, 緩衝液濃度々接種ササゲ葉上の local lesion 数との 関係，純化ウイルスの紫外線吸収曲線等の結果が記 されている。この実験で抗血清の吸収試験や，タバ コ以外の $\mathrm{CMV}$ 寄主植物との抗血清反応試験が行わ れていないのは残念である。

（栃原比呂志）

\section{土に施した殺虫剂，除草剂のトマト夏疫病と萎调 病の発生に及仿す影響}

Richardson, L.T. : Effect of insecticides and herbicides applied to soil on the development of plant diseases.

II. Early blight and Fusarium wilt of tomato Canad. Journ. Plant Sci., 39 (1) : 30 38.
(1959).

殺虫阂や除草剤を土に施すと，病害がいかに消長 するかをトマトの夏疫病（病原菌, Alternaria solani) と萎调病（病原菌，Fusarium oxysporum f. lycopersici)で研究した。大部分の薬㓮はトマトに薬 害があり, lindane, manuron, schradan, demeton, などがひどいが, aldrin, DDT, endrin, delapon などはかえつて生育を促進した。

夏疫病では薬郕を10 日間連日土壤に施した後, 分生子を幼苗の葉に接種した。 lindane, 2,4-D, isodrin では発病がふえ, endrin, MH, NPA, dieldrin, IPC, delapon, demeton, aldrin などで は発病が減つた。

萎调病では薬剤の施用時期と発病との関係を見た が(接種は根を胞子浮遊液に浸漬した)，施用時期と 無関係に lindane, isodrin, delaponなどでは発病 がふ光, TCA, DDT, dinoseb, endrin, aldrin(後 2 者は薬昘施用後接種）などでは発病が減つた。 2,4-D と MHは施用時期により発病が増減したが， 免疫性品種を発病させることはできなかつた。

dinoseb, aldrin demeton はすでに 2,3 の病害 の発生を少なくすることが報告されているが，本研 究でも抑制効果のあつたのは面白い。これらの薬棛 が発病に影響する機構は，（1）薬が直接菌に作用 乙て感染が減る。（2）宿主に作用して抵抗性を增減 させる。ことなどが考えられる。前者には dinoseb があてはまり，試験管内でも菌に有毒であるが，空 気伝染性の夏疫病には菌々直接接触しないので，き かなかつた。後者については，ホルモン型の除草剮 ではすでに論議されているが，それ以外の薬剤の作 用機棈は不明である。

（箈 永 時 任） 